\title{
CAROTID BODY TUMOUR
}

\author{
By K. R. Lothian, M.B., F.R.C.S., Senior Surgical Registrar \\ and W. E. B. ScoTT, M.B., F.F.A.R.C.S., Late Anaesthetic Registrar \\ Royal Southern Hospital, Liverpool
}

We wish to present a case of carotid body tumour with syncopal attacks. There are many accounts of carotid body tumours in the literature; Monro (1950) collected records of 223 cases and added five more. However, there are very few records of these tumours associated with sinus syncope. McSwaine and Spencer (1947) could find only six such cases and they added two of their own.

\section{Case Report History}

J. McA., a male aged 47 years, was first seen at a medical clinic of the Royal Southern Hospital on June I, 1954. He was complaining of attacks of unconsciousness for the past ten months. At first he had two or three fits a week, but they were now occurring as often as four or five times a day. The attacks were preceded by a buzzing in the left ear and were often followed by a left frontal headache. There had been 'soreness' of the left side of the neck since September 1953, and he had occasionally fainted when shaving this area. He had been conscious of a slowing of the pulse rate for the past ten months. His wife stated that he remained unconscious for a minute or two, that he jerked slightly and that he frequently wet his clothes.

\section{On Examination}

The patient was a healthy looking middle-aged man-B.P. I Io/75, P.R. 44-50. There was a vague swelling in the region of the left carotid bifurcation and even the most gentle examination of this area caused the patient to become pale and lose consciousness. If palpation was continued convulsive movements followed. During a typical attack the pulse stopped for 20 seconds and then recommenced at 36 beats per minute. The blood pressure dropped almost to zero.

A diagnosis of carotid body tumour was made.

\section{Investigations}

W.R.: Negative.

E.C.G.: Bradycardia but otherwise normal.
E.E.G.: At rest there was a somewhat irregular 9/sec. alpha rhythm over the posterior part of the hemispheres and also a little irregular rapid activity. The lump was massaged with loss of consciousness, but no significant change in the record.

Manual obliteration of the left common carotid artery produced no abnormality in the record.

Chest and cervical spine X-ray-no abnormality seen. Carotid angiogram showed no abnormality of left carotid vessels. Right carotid angiogram performed with the left common carotid artery compressed showed filling of the anterior and middle cerebral vessels of the left side.

The effect of various drugs, administered intravenously, on the reflex sinus syncope was determined.

It was found that I.V. Atropine gr. I/50 caused the pulse rate to increase to 120 and provided complete protection from the effects of pressure on the tumour for $15-20$ minutes. After 20 minutes, pressure produced progressively greater slowing of the pulse although unconsciousness could not be induced until about 70 minutes after the injection of Atropine.

Pethidine I.V. in doses up to $100 \mathrm{mg}$. produced no marked change in pulse rate and provided no protection from syncope.

Procaine, I per cent. intravenously, increased the pulse rate slightly, but only prevented fainting after pressure when the rate of injection was such as to produce the toxic effects of profuse sweating, skin tingling and mental confusion. At slower rates of injection syncope was readily produced by palpation of the tumour.

Chlorpromazine $50 \mathrm{mg}$. I.V. produced an increase in pulse rate to 80 . Subsequent pressure on the tumour resulted in syncope, but the pulse rate remained around 50 during this period.

\section{At Operation (Mr. J. Cosbie Ross)}

A long incision was made along the anterior border of the left sterno-mastoid muscle. The common, internal and external carotid arteries were all identified and Penrose rubber drain was 
TABLE I

\begin{tabular}{|c|c|c|c|c|c|c|c|c|c|c|c|c|c|}
\hline $\begin{array}{l}\text { Time: } \\
\text { Mins. after } \\
\text { Start Anaes.: }\end{array}$ & $\circ$ & 4 & 25 & 35 & 37 & 50 & 60 & 63 & 70 & 80 & 90 & Iro & $\begin{array}{l}\text { 3 Hrs. } \\
\text { Post- } \\
\text { op. }\end{array}$ \\
\hline Pulse .. & 60 & 80 & 60 & 54 & 120 & 120 & II 8 & I 15 & 100 & 85 & 80 & 80 & 72 \\
\hline B.P. $\quad$. & $130 / 70$ & $120 / 60$ & $95 / 65$ & $85 / 60$ & $110 / 70$ & $85 / 60$ & $55 / ?$ & $120 / 80$ & $125 / 80$ & $100 / 70$ & $110 / 70$ & $95 / 65$ & $110 / 70$ \\
\hline Chlorpromazine & $50 \mathrm{mg}$ & & & & & & & & & & & & \\
\hline Thiopentone .. & $500 \mathrm{mg}$ & & & & & & & & & & & & \\
\hline Pethidine & $25 \mathrm{mg}$. & & & & & & & & & & & & \\
\hline Atropine & & & & gr.r/4o & & & & & & & & & \\
\hline Nor-adrenaline & & & & & & & Drip & Drip & Drip & Drip & & & \\
\hline
\end{tabular}

passed around each to act as a retractor and clamp if necessary. The tumour was tightly wedged in the bifurcation of the vessels, the bulk of it being deep to the vessels on the pharyngeal wall. The separation of the tumour from the arteries was fairly easy until the lower end was reached where it was closely adherent. Here a tear about $5 \mathrm{~mm}$. long was made in the junction of the common and internal carotids. This was repaired by rotating the vessels after ligation and division of the external carotid. Pulsation in the internal carotid after removal of the clamps was excellent, although there was some constriction at the site of the repair. The wound was closed without drainage.

\section{Anaesthetic}

Pre-medication: Pethidine roo mg. Atropine gr. I/50 three-quarters of an hour before the operation.

Induction: Chlorpromazine $50 \mathrm{mg}$. I.V. followed by Thiopentone $500 \mathrm{mg}$. and Pethidine $25 \mathrm{mg}$. The larynx was sprayed with 2 per cent. Xylocaine and an oral endotracheal tube passed.

Maintenance: Nitrous oxide, oxygen and minimal Trilene through an open T-piece circuit with intermittent Pethidine. It was found necessary to give Atropine gr. I/40 during operation to maintain the pulse rate, and for a short period a nor-adrenaline drip $(\mathrm{I} / 350,000)$ was necessary to maintain the B.P. at a safe level.

At the conclusion of the operation a left stellate ganglion block was carried out with Xylocaine I per cent.

The B.P. and pulse readings during operation are given in Table $\mathrm{I}$.

\section{Post-operative Course}

Immediately after operation the pulse rate was $80 / \mathrm{min}$. and it continued at this rate. No more fits occurred. There was a slight weakness in the distribution of the cervical branch of the left facial nerve but no evidence of any intracranial $\omega$ damage. The wound healed well and the patient. $\checkmark$ was discharged from hospital nine days after the $\vec{A}$ operation. When last seen six months later he had had no recurrence of symptoms and firm 5 pressure over the site of the tumour produced no effect at all. The B.P. was $120 / 80$ and the pulse rate was $76 / \mathrm{min}$.

Pathological Report (Dr. C. St. Hill)

Carotid Body Tumour. The tumour is encapst lated, lobulated, firm and homogeneous, white colour and measures about $2 \frac{1}{2} \mathrm{~cm}$. in size. It Ts marked with a groove, the impression of the carotid artery.

Histologically, the appearances are those of $a \stackrel{2}{\Phi}$ carotid body tumour. The growth consists of $\overrightarrow{\vec{P}}$ masses of large pale polyhedral cells separated 3 by connective tissue and by blood vessels. The cellular margins are indistinct and some of the cells appear to be vacuolated. No mitotic figures are apparent and the growth appears to be benign 3 . in nature.

\section{Discussion}

These tumours are of sufficient rarity to make it unlikely that the average surgeon will have to treat more than one or two in a lifetime. There- $>$ fore it is desirable that he be able to obtain aso much help as possible, in what may be a difficult problem, from the literature.

The main course of trouble is due to the close 0 relationship of the tumour to the bifurcation of the carotid artery. It may not be possible to remove the tumour without the sacrifice of the common and internal carotid arteries. Ligation of the internal carotid artery has carried a mor- $\stackrel{\oplus}{+}$ tality varying from 30 to 50 per cent. in different 0 series (Dandy, 1942). In view of this, Lahey and Warren (195I) have suggested that if the 
tumour cannot be removed without endangering the carotid vessels it should only be biopsied. If the biopsy shows it to be benign no further surgery should be undertaken. In their series of 22 cases there was no case of proved malignancy. They believe the incidence of malignancy to be low and they quote Gratiot (1943) as giving it as I 5-20 per cent.

However, in the present instance it was obvious that an attempt would have to be made to remove the tumour in view of the frequency of disabling syncopal attacks.

It is important that attempts should be made to assess before operation the likelihood of the occurrence of serious cerebral damage if resection of the bifurcation becomes necessary. Matas (1934) recommended compression of the common carotid against Chassaignac's tubercle to see if any faintness occurred, whilst Lambert Rogers (1947) suggested exposure of the common or internal carotid under local anaesthesia and temporary occlusion of the vessel whilst an electro-encephalogram was performed. At the same time he compared the muscular function of the two sides, using a dynamometer. Both of these methods seem to be unreliable when attempting to predict what will happen if the bifurcation is resected. Possibly a more helpful method would be a crosscirculation carotid angiogram with compression of the carotid artery on the side of the lesion.

Attempts have been made to improve the collateral cerebral circulation pre-operatively by repeated manual compression of the common carotid several times a day, but this is no guarantee against major cerebral damage if the vessels have to be ligated (Hendrick, 1952; Lahey and Warren, 1951). Dandy (1942), working on the problem of internal carotid ligation for intracranial aneurysm, found that preliminary partial ligation of the common carotid reduced the mortality to 4.5 per cent.

If a suitable arterial graft is available it would be possible to reunite the common and internal carotid arteries and thus preserve the cerebral circulation. Should no graft be available and excision of the bifurcation be necessary, Hendrick (I952) suggests that the internal carotid be ligated as close to the base of the skull as possible and so reduce the length of artery, below the circle of Willis, in which a thrombus could form and later give rise to a cerebral embolus. He also advocates the use of anticoagulants. Conley and Peck (1952) recommend the union of the cut distal ends of the internal and external carotid arteries as they claim that some blood may thus reach the brain via the anastomoses between the two external carotids.

\section{Effects of Drugs and Anaesthesia}

All the drugs investigated for their effect upon the reflex syncope are possessed to a greater or lesser degree of some vagolytic property. As might be expected, Atropine was by far the most efficient in this respect as evidenced by the tachycardia following its administration.

Perhaps the most interesting observation, however, was that, although the pulse rate did not drop below 50 after the administration of Chlorpromazine, loss of consciousness occurred on palpating the tumour. This would seem to indicate that the fall in B.P. was only partially due to the fall in heart rate and partially due to reflex vasodilatation. This surmise is borne out by a study of the B.P. and pulse recordings during operation (Table I); 35 minutes after the induction of anaesthesia the pulse rate was 54 and the B.P. $85 / 60$. Following the I.V. injection of Atropine gr. I/40 the pulse rate rose to 120 and the B.P. to $110 / 70$. During the next 20 minutes, however, the B.P. gradually fell to 55/? despite the pulse remaining between 105 and 120 . At this point the Nor-adrenaline drip was started and the rate of flow regulated to maintain the B.P. at about $120 / 80$. It was found necessary to continue this drip until just shortly before the complete removal of the tumour, a period of 20 minutes later. Thereafter the B.P. remained steady unaided, the pulse remaining between 80 and 90.

Goldberg (1947) states that the fainting attacks may be either due to an associated sensitive carotid sinus or to direct pressure on the reflex arc, and recognizes two types of syncope depending upon whether the vagus pathway or vasomotor depressor pathway predominates. In the first type the B.P. falls in association with a fall in pulse rate, whereas in the second type the fall in B.P. is caused by vasodilatation. It would seem clear from our observations that both pathways were stimulated in this case.

It is interesting to note that in previous accounts of operations on carotid body tumour associated with sinus syncope only once has syncope during operation been recorded (Migniniac, 1937).

McSwaine and Spencer (1947) describe two cases anaesthetized with endotracheal nitrous oxide, oxygen and ether, and in both the reflex alteration in B.P. and pulse disappeared when anaesthesia was established.

Goldberg (1947) describes one case which was anaesthetized with nitrous oxide, oxygen and ether, and here again after anaesthesia was established no change in pulse or B.P. could be produced by pressure on the tumour.

Monro (r950) concludes that the reflex is abolished under general anaesthesia. 
It would appear from the above that the reflex is indeed abolished when some of the more potent anaesthetics such as ether are used. Unfortunately, these have usually some other disadvantages, such as toxicity or inflammability, and at the present time with the widespread use of the diathermy, etc., they are usually contraindicated. The fact that less potent agents and combinations such as gas, Pethidine and light Trilene do not greatly depress the reflex was well demonstrated in this case. That this is of little consequence, however, is equally clear since it is comparatively simple to nullify the effects of the reflex by employing drugs with vagolytic and sympathomimetic properties. The agents of choice would seem to be Atropine and Nor-adrenaline.

\section{Suggested Scheme of Treatment}

1. Preliminary assessment of state of collateral cerebral circulation by electroencephalogram and crossed carotid angiogram.

2. Exploration of tumour through a long incision along the anterior border of sterno-mastoid to give a wide exposure.

3. If possible to remove the tumour without jeopardizing the internal and common carotid vessels, do so.

4. If not, apply a temporary ligature to the common carotid, partially occluding it, and biopsy the tumour.

5. If the biopsy shows the tumour to be malignant, or if the symptoms warrant it, re- explore three weeks later and excise the tumour together with the bifurcation of the carotid.

6. If possible, insert an arterial graft, but if not anastomose the distal cut ends of the internal and external carotids.

7. Carry out a stellate ganglion block with local anaesthetic.

8. Give anticoagulants post-operatively.

9. Nurse in head-down position in an oxygen tent for several days.

\section{Summary}

A case of carotid body tumour with marked sinus syncope is described.

The problem of treatment of these tumours is discussed and a plan of treatment is given.

The effects of various drugs on the syncopal attacks are discussed.

Our thanks are due to Dr. R. R. Hughes, under whose care the patient was admitted, and to Mr. J. Cosbie Ross, who performed the operation, for permission to publish this case.

\section{BIBLIOGRAPHY}

CONLEY, J. J., and PACK, G. T. (1952), Surgery, 3I, 845 . DANDY, W. E. (1942), Arch. Surg., 45, 521.

GOLDBERG, H. M. (1947), Brit. F. Surg., 34, 295

GRATIOT, J. H. (1943), quoted by Lahey and Warren.

HENDRICK, J. W. (I952), Surgery, 31, 385. LAHEY, F H., and Clinic', I40, Philadelphia. MCSWAINE, B., and SPENCER, F. L. (1947), Surgery, 22, 222. MATAS, R. (1934), Amer. F. Surg., 24, 692.

MIGNINIAC, M.'(1937), Mem. Acad. Chir. (Paris), 63, 165.

MONRO, R. S. (1950), Brit. F. Surg., 37, 445.

ROGERS, L. (r947), ibid., 35, 43.

Bibliography continued from page 1 30-S. Fazlullah, M.B.(Osmania), D.T.M. \& H.

\section{BIBLIOGRAPHY}

ADAMS, R. D. (1955), ' Text Book of Medicine,' by CECIL, R. .L, and LOEB, R. F., 1548 .

AEGERTER, E., and LONG, J. H. (1949), Amer. F. med. Sci., 218, 324.

ARING, C D. (1945), Internat. Clin., 4, 262.

ASHBY, D. W., and LAZAR, T. (195I), Lancet, i, I091.

BARNES, J., and BARNES, E. (1955), Lancet, i, 455.

BEHCET, H. (1937), Derm. W Wchr., IO5, 1152 .

BEHCET, H. (1939), Bull. Soc. franc. Derm. Syph., 46, 674.

BEHCET, H. (1940), Dermatologica. Basel, 81, 73.

BENDA, C. E. (I949), Arch. Neurol. Psychiat., 6r, 137.

BLACKWOOD, W. (1956), P, oc. Roy. Soc. Med., 49, 146.

BREUTSCH, W. L. (1942), Trans. Amer. neurol. Ass., 68, 17.

BYWATERS, E. G. L. (1956), Proc. roy. Soc. Med., 49, 287.

CAMPBELL, B., and GOOD, R. A. (I950), Arch. Neurol. Psychiat., $63,298$.

CAVANAGH, J. B. (1953), f. clin. Path., 6, 128.

CHURG, J., and STRAUSS, L. (195I), Amer. $\dot{\mathcal{F}}$. Path., 27, 277.

CLARK, E. C., and BAILEY, A. A. (1956), भ. Amer. med. Assoc.,

I60, 455 .

CLOAKE, P. C. P. (195I), 'Modern 'Trends in Neurology,' by Feiling, A., 466 .

CLOAKE, P. C. P. (1953), V. Internat. Neurol. Congress, I, 25.

COLOVER, J. (1954), Brain, 77, 435.

COLOVER, J., and CONSDEN, R. (1955), Excerpta. med. (Amst.), Sect. VIII, 8, 808 .

COLOVER, J. (1956), Proc. roy. Soc. Med., 49, 154.

COOKE, W. T., CLOAKE, P. C. P., GOVAN, A. D. T., and COLBECK,' J. C. (1946), Quart. F.'Med., 15, 47

DARMADY, E. M., GRIFFITHS, W. J., SPENCER, H., MATTINGLY, D., STRANAK, F., and WARDENER, H. E. DE (1955), Lancet, i, 378.

DIAMOND, J. (1936), Ұ. Pediat., 8, 697.
DIAZ-RIVERA, R. S., and MILLER, A. J. (1946), Ann. Intern. Med., 2I, 628.

EDGE, J. R., FAZLULLAH, S., and WARD, J. (1955), Lancet, EHRENREICH, T., and OLMSTEAD, E. V. (I95I), Arch. Path., EVANS, 145 .

, Yale F. Biol. Med., 20, I9.

LLAH, S. (1956), Postgrad. med. F., 32, 150.

GAIRDNER, D. (1948), Quart. F. Med., 17, 95.

GRANT, H., and LEOPOLD, H. N. (1954), $\mathscr{F}$. Amer. med. Ass., $155,252$.

GREENFIELD, J. G. (1950), Brain, 73, 141.

GRUBER, G. B. (1925), Arch. f. Path. Anat., 258, 44 I.

GUILLAIN, G., BARRE, J. A., and STROHL, A. (I9I6), Bull. et mém. Soc. méd. d. hóp. de Paris, 40, 1462.

HAM, A. W. (1940), Arch. Path., 29, 731.

HARGRAVES, M. M., RICHMOND, H., and MORTON, R. (1948), Proc. Staff Meeting, Mayo Clin., 23, 25.

HAYMAKER, W., and KERNOHAN, J. W. (1949), Medicine,

HEATHFIELD, K. W. G., and WILLIAM, J. R. B. (1954),

LORTet, ii, 673 . Proc. Mayo. Clin., 7, 700 .

KABAT, E. A., WOLF, A., and BEZER, A. E. (1947), F. exp. Med.,

KERNOHAN, J. W., and WOLTMAN, H. W. (1938), Arch: Neurol. Psychiat., 39, 655 .

KLEMPERER, P. (1948), Ann. intern. Med., 28, I.

KLINGE, F. (1929), Beitr. path. Anat., 83, 185.

KNOWLES, H. C., ZEEK, P. M., and BLANKENHORN, M. A. (1953), Arch. Int. Med., 92, 789.

KULKA, J. P., BOCKING, D., ROPES, M. W., and BAUER, W. (1955), Arch. Path., 59, 129. 
Bibliography continued from previous page-S. Fazlullah, M.B.(Osmania), D.T.M. E H.

KUSSMAUL, A., and MAIER, R. (1866), Dtsch. Arch. klin. Med., LIVE, 484.

LONG, D. A. (1954), ibid., i, 529.

LONG, D. A. (1955), Int. Arch. Allergy, N.Y., 6, 337.

LONG, D. A. (1956), Proc. roy. Soc. Med., 49, 205

LOVSHIN, L. L., and KERNOHAN, J. W. (1948), Arch. Int. Med., 82, 321 .

LUBENS, H. M. (1955), Ann Allergy, 13, 265.

LUMSDEN, C. E. (1949), Brain, 72, 198.

LUMSDEN, C. E. (1956), Proc. roy. Soc. Med., 49, 148.

MALAMUD, N., and FOSTER, B. D. (1942), Arch. Neurol. Psychiat., 47, 828 .

MCALPINE, D.' (1931), Lancet, i, 846.

MCALPINE, D. (I956), Practitioner, 176, 123.

MCCORMIĆK, R. V. (1950), F. Amer. med. Ass., 144, 1453.

MILLER, H. G. (1949), Proc. roy. Soc. Med., 42, 497.

MILLER, H. G. (1953), Brit. med. F., i, 846 .

MILLER, H. G. (1956), Proc. roy. Soc. Med., 49, 139.

MILLER, H. G., and EVANS, M. J. (1953), Quart. F. Med., 22, 347.

NEALE, A. V., and WHITFIELD, A. G. W. (r934), Brit. med. F., ii, ro4.

O'BRIEN, D. J., and STOREY, G. (1954), ibid., i, 792.

OPHULS, W. (1923), Arch. int. Med., 32, 870.
POLLEY, H. (1956), Brit. med. $\mathcal{F}_{.,}$ii, 15 r.

RICH, A.' R., and GREGORY, J. E. (1943), Bull. Fohns Hopk. Hosp., $72,65$.

RICH, A. R. (1946/47), Harvey Lecture, 42, 106.

RICH, A. R. (1942), Bull. Johns Hopk. Hosp., 71, 123.

RUNGE, W., and MELZER, H. (r930), f.' Psych. Neurol. (Lpz.),

RUSSEL 298. D. S. (1937), F. Path. Bact., 45, 357.

RUSSELL, D. S. (1955), Brain, 78, 360.

SELYE, H., BELAND,' E., and SYLVESTER, O. (1944), Exp. Med. Surg., 2, 224.

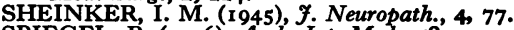

SPIEGEL, R. (1936), Arch. Int. Med., 58, 993.

SOUIER, T. L., and MADISON, F. W. (1937), f. Allergy, 8, 143. TOWERS, A. G. (1955), Lancet, ii, 143 .

VESZPREMI, D., and JANCSO, M. (1903), Beitr. path. Anat.,

WAKSMAN, B. H., and ADAMS, R. D. (1955), f. exp. Med.,

WINKELMAN, N. W., and ECKEL, J. L. (1932), Arch. Neurol.

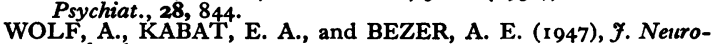
path., 6, 333 .

ZEEK, P.' M. (1952), Amer. F. clin. Path., 22, 77.

ZEEK, P. M. (1953), New Eng. F. Med., 248, 764.

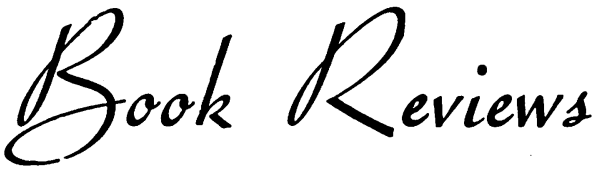

\section{A TEXTBOOK OF MENTAL DEFICIENCY}

By R. F. Tredgold, M.D., D.P.M., and K. Soddy, M.D., D.P.M. Ninth Edition. Pp .xv +480 , with 3 I plates. London: Bailliere, Tindall \& Cox. 1956. 40s.

First published in 1908 , and now in its ninth edition, 'Tredgold's Mental Deficiency' still remains the best book on the subject in the English language. This new edition brings in some outstanding changes, however, all of them for the better, and this follows from Dr. Tredgold taking over the work from his father, the late Dr. A. F. Tredgold, with the assistance of his colleague, Dr. Soddy. While the authors have been careful to preserve the noteworthy features of the earlier editions, namely, the clinical descriptions, the rest of the book has been rewritten in the light of contemporary research and recent developments in the psychological theory of mental deficiency. A number of plates have been omitted, and others have been brought up to date; the latter is certainly overdue, for even the last post-war edition contained many photographs taken, to judge by the dress, half a century ago. The development of what has been called 'biosocial medicine'-particularly in the last decade-is reflected by the emphasis placed on the home environment of the defective, his education and rehabilitation, and in the sections on the sociological implications of mental deficiency in its community setting, the authors have made a most valuable contribution. It is perhaps a pity that the term ' amentia' finds support in this book for its increasing use. While not etymologically incorrect, the word has a different connotation on the Continent. The Italian amenza means, and is used for, confusional insanity, and elsewhere in Europe, and particularly Holland, amentia is regarded as this form of psychosis. If we must have a medical term to replace 'mental deficiency,' the generally acceptable term of oligophrenia would be preferable, particularly since this work enjoys such a high reputation abroad. Mental deficiency, in one aspect or another, touches almost every branch of medicine, and this classical text remains an essential reference book, while the innovations due to its change of authors outdate all previous editions and makes imperative their replacement.

\section{L.R.C.N.}

\section{PERIPHERAL VASCULAR DISORDERS}

By D. I. Abramson, M.D., F.A.C.P. Pp. $x v+537$, with 82 illustrations. London: Cassell \& Co. Ltd. 1957. £5 $5 \mathrm{~s}$.

Dr. Abramson is to be congratulated on this book which is an up-to-date practical guide to peripheral vascular disorders. As indicated by the title, diagnosis and treatment are the theme of the book with little discussion of pathology or aetiology. It is 